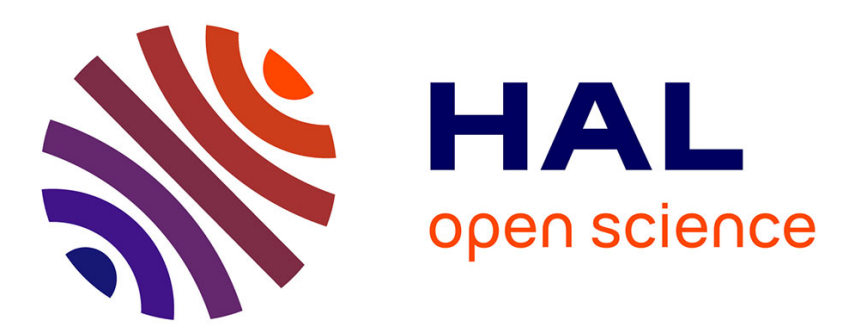

\title{
Germination and inactivation of Bacillus subtilis spores induced by moderate hydrostatic pressure.
}

Hue Nguyen Thi Minh, Philippe Dantigny, Jean-Marie Perrier-Cornet, Patrick Gervais

\section{- To cite this version:}

Hue Nguyen Thi Minh, Philippe Dantigny, Jean-Marie Perrier-Cornet, Patrick Gervais. Germination and inactivation of Bacillus subtilis spores induced by moderate hydrostatic pressure.. Biotechnology and Bioengineering, 2010, 107 (5), pp.876-83. 10.1002/bit.22849 . hal-00691825

\section{HAL Id: hal-00691825 \\ https://hal.science/hal-00691825}

Submitted on 27 Apr 2012

HAL is a multi-disciplinary open access archive for the deposit and dissemination of scientific research documents, whether they are published or not. The documents may come from teaching and research institutions in France or abroad, or from public or private research centers.
L'archive ouverte pluridisciplinaire HAL, est destinée au dépôt et à la diffusion de documents scientifiques de niveau recherche, publiés ou non, émanant des établissements d'enseignement et de recherche français ou étrangers, des laboratoires publics ou privés. 
Germination and inactivation of Bacillus subtilis spores induced by moderate

\section{hydrostatic pressure}

Hue Nguyen Thi Minh, Philippe Dantigny, Jean-Marie Perrier-Cornet* and Patrick Gervais Laboratoire de Génie des Procédés Microbiologiques et Alimentaires, AgroSup Dijon, Dijon, France

Corresponding author: Tel.:+33 380396845; Fax: +33 380772385

E-mail address: jperrier@u-bourgogne.fr 


\begin{abstract}
In this study, we investigated the mechanisms of spore inactivation by high pressure at moderate temperatures to optimize the sterilization efficiency of high-pressure treatments. Bacillus subtilis spores were first subjected to different pressure treatments ranging from 90 to $350 \mathrm{MPa}$ at $40{ }^{\circ} \mathrm{C}$, with holding times from $10 \mathrm{~min}$ to $4 \mathrm{~h}$. These treatments alone caused slight inactivation, which was related to the pressure-induced germination of the spores. After this pressure treatment, the sensitivity of these processed spores to heat $\left(80{ }^{\circ} \mathrm{C} / 10 \mathrm{~min}\right)$ or to high pressure $\left(350 \mathrm{MPa} / 40{ }^{\circ} \mathrm{C} / 10 \mathrm{~min}\right)$ was tested to determine the pressure-induced germination rate and the advancement of the spores in the germination process. The subsequent heat or pressure treatments were applied immediately after decompression from the first pressure treatment or after a holding time at atmospheric pressure. Our results show that high pressure was necessary and very efficient in inducing spore germination. However, it seemed to slow the enzymatic digestion of the cortex, which is required for germinated spores to be inactivated by pressure. Although these results indicate that high-pressure treatments are more efficient when the two treatments are combined, a small spore population still remained dormant and was not inactivated with any holding time or pressure level.
\end{abstract}

Keywords: bacterial spores; Bacillus subtilis; high pressure; germination; inactivation

\title{
Introduction
}

Under starvation conditions, Bacillus species can form endospores, which are metabolically dormant and physically very resistant. Bacterial spores exhibit a multilayer structure in which each layer plays an important role in protecting the spore against environmental perturbations. Bacterial spores are considered to be the most resistant life form among biological models and can survive for millions of years (Vreeland et al., 2000). The extreme resistance of bacterial spores to many stresses has been reported, including to external desiccation (Dose and Gill, 
1995), very high pressure (Margosch et al., 2004), UV radiation, heat, and chemical agents (Setlow, 2006), and this resistance is therefore an important obstacle to food preservation. The only reliable industrial method of spore inactivation is heat treatment for about 20 min at 120 ${ }^{\circ} \mathrm{C}$, which is widely used for food sterilization in the industry. However, this thermal process has some drawbacks insofar as it modifies not only the sensory qualities (color, flavor, texture) but also the nutrient content of foodstuffs. High-pressure treatments have stimulated considerable interest in the food industry because they not only preserve the nutritional and organoleptic food qualities, but also reduce the energy and time required for processing (Tewari et al., 1999). However, this alternative technology fails to achieve the efficient destruction of bacterial spores. In fact, spore inactivation by high pressure at ambient temperature is not sufficiently efficient and some spores are even reported to survive after a treatment at $1034 \mathrm{MPa}$ for $90 \mathrm{~min}$ at $35{ }^{\circ} \mathrm{C}$ (Timson and Short, 1965). Combining high pressures with moderate temperatures (Clery-Barraud et al., 2004) or pressure cycling (Furukawa et al., 2003) could improve spore inactivation but the complete destruction of bacterial spores at moderate temperatures has not so far been achieved.

The phenomena involved in the spore inactivation induced by high pressure differ from those identified in vegetative cells. It has been reported that pressure induces cell inactivation by cell permeabilization, the subsequent leakage of internal solutes, and cell shrinkage (PerrierCornet et al., 1995, 1999) or by protein denaturation (Alpas et al., 2003). These phenomena are normally reinforced by the increased pressure. On the contrary, Sale et al. (1970) found an optimal pressure for Bacillus subtilis spore destruction at about $250 \mathrm{MPa}$, in the pressure zone ranging from 100 to $800 \mathrm{MPa}$ at $25{ }^{\circ} \mathrm{C}$, with a $1 \mathrm{~h}$ holding time (Sale et al., 1970). This atypical inactivation curve seems to be the result of spore germination, which is intimately involved in spore inactivation by pressure. In fact, hydrostatic pressure triggers the spore germination phenomenon and during this process, spores progressively lose their typical 
resistance and become more readily inactivated (Moir, 2006; Setlow, 2003), like vegetative cells.

The germination phenomenon can also be induced by other factors (nutrients or abrasion) (Jones et al., 2005; Paidhungat et al., 2002; Rode and Foster, 1960; Setlow et al., 2003). Spore germination is generally divided into different stages but the distinction and the quantification of those germination stages are not clear. The release of dipicolinic acid (DPA) may only be useful in studying the onset of the germination process (Moir, 2006), whereas visualization of protein mobility (Cowan et al., 2004; Moir, 2003), the drop in optical density, or increased spore permeation to fluorescent substances only occur in the late stages. The use of flow cytometry coupled to fluorescent probes has recently been reported to differentiate different spore populations after pressure treatments, but the identification of these populations is complex (Mathys et al., 2007). In this study, we tried to differentiate the different stages in the germination process by identifying the spore sensitivity to heat and high pressure, as shown in Figure 1.

In the first stage, spores partially lose their impermeability to water, leading to water influx (with a slight increase in volume) and solute (DPA, $\mathrm{Ca}^{2+}$ ) leakage. Consequently, they become sensitive to wet heat (Setlow, 2003). During the second stage, the cortex is enzymatically digested, leading to full core rehydration, greater hydration of the core macromolecules and a greater loss of spore-specific resistance (to high pressure, for example; Wuytack et al., 1998). It has already been reported that pressure (600 MPa)-germinated spores, which were sensitive to heat but still resistant to high pressure (Wuytack et al., 1998), had characteristics similar to those of spores genetically blocked at stage I, and were induced by nutrients (Setlow et al., 2001).

At the end of stage II, the small acid-soluble spore proteins (sasP) are hydrolyzed to amino acids, which are subsequently used in protein synthesis by the growing cell (Moir, 2006; 
Setlow, 2003). Protein synthesis and spore metabolism only occur in the outgrowth phase, in which the germinated spore is converted into a growing cell. However, the small endogenous energy reserves (3-phosphoglyceric acid constitutes $0.3 \%$ of the spore dry weight and sasP constitute $3.5 \%$ of the spore dry weight) do not allow spore outgrowth without external nutrients. In fact, spores lack some enzymes, which require external substrates for their synthesis (Paidhungat and Setlow, 2002). After the germination and outgrowth phases, and under favorable conditions, bacterial cells can undergo a multiplication process and colonize the medium. They may even produce toxins in foodstuffs. Without control, the spore germination induced by high pressure can be a risk to foods.

The aim of this work was to study the germination and inactivation of bacterial spores induced by moderately high pressures and the effects of different factors on these two processes to gain insight into the mechanisms of spore inactivation by high pressure. Our results might help to optimize the barosterilization process.

\section{Materials and methods}

\section{Bacterial strains and growth conditions}

The strain used was Bacillus subtilis ATCC 31324 (DSMz 704) obtained from Deutsche Sammlung von Mikroorganismen und Zellkulturen (Braunschweig, Germany). The sporulation of $B$. subtilis was induced in a reactor in a complex medium at $37^{\circ} \mathrm{C}, \mathrm{pH} 8.0$, with an air flow of $4 \mathrm{~L} \mathrm{~min}^{-1}$ and with agitation (450 $\mathrm{rpm} \mathrm{min}^{-1}$ ) (Nguyen Thi Minh et al., 2008). Sporulation was estimated by counting the spores before and after a heat treatment at $80{ }^{\circ} \mathrm{C}$ for 10 min. Bacillus subtilis spores were harvested when sporulation reached more than 95\% of the cell population (about $48 \mathrm{~h}$ ). The spores were washed three times with sterile distilled water and spray-dried. 


\section{High-pressure treatment}

\section{Sample preparation}

Spore powder was suspended in sterile distilled water at a final concentration of approximately $10^{9}$ spores $\mathrm{mL}^{-1}$. Samples of about $1 \mathrm{~mL}$ of the spore suspension were transferred to sterile polyethylene bags, which were aseptically heat-sealed and stored at room temperature until treatment.

\section{High-pressure treatments}

High-pressure treatments were applied using a 1.5 L vessel (GEC Alsthom ACB, France), which was maintained at a constant temperature $\left(40 \pm 3{ }^{\circ} \mathrm{C}\right)$ and was capable of operating at up to $600 \mathrm{MPa}$. Hydrostatic pressure was generated with a hydraulic high-pressure pump (Hydro Process, France) connected to the vessel. The pressure and temperature inside the vessel were controlled by a pressure gauge (Sedeme, France) and a K-type thermocouple (Top Industrie, France), respectively. High-pressure treatments were applied at 90-450 MPa, with holding times ranging from $0 \mathrm{~min}$ to $4 \mathrm{~h}$. All high-pressure treatments were applied at $40{ }^{\circ} \mathrm{C}$ in this study. Pressure loading and unloading were performed at approximately $12 \mathrm{MPa} \mathrm{s}^{-1}$. For treatments with a holding time of 0 min, decompression was initiated immediately after compression.

\section{Heat treatment}

Spore samples, prepared as previously described, were maintained at $80{ }^{\circ} \mathrm{C}$ in a water bath for $10 \mathrm{~min}$. The heat-treated samples were cooled by immersion in a water bath maintained at room temperature.

\section{Viability measurements}

Viability measurements were made according to the colony-forming-unit method. After dilution in physiological water $(9 \% \mathrm{NaCl} w / w)$, the microbial suspensions were manually 
spread over Columbia agar medium (Biokar Diagnostics, France) and incubated at $37{ }^{\circ} \mathrm{C}$ for $24 \mathrm{~h}$.

\section{Quantification of different spore populations during germination}

In this study, the germination process was expected to stop in the early phase of stage II because in the absence of nutrients, spores cannot establish the active processes necessary for the recovery of the vegetative state. This fact was verified by microscopic observations. After the pressure treatment, the initial population of native spores (NS) was partially replaced by germinated spores at different stages (stage I [GI] and stage II [GII]) in the suspension, as shown in Figure 1. Each population exhibits corresponding morphological changes and is associated with the loss of specific resistance (Setlow, 2003). Including a heat treatment (80 ${ }^{\circ} \mathrm{C} / 10 \mathrm{~min}$ ) after the initial pressure treatment allowed us to distinguish each population of germinating spores, as summarized in Table I. Because spontaneous germination was rare, all heat-sensitive spores must have been induced by pressure and achieved at least stage I of the germination process. We observed that the number of spores sensitive to heat increased progressively during maintenance at atmospheric pressure for $4 \mathrm{~h}$ and remained constant thereafter (up to $24 \mathrm{~h}$ ). Therefore, all the heat-resistant spores observed after this delay were assumed to have remained native spores and their germination was not induced by pressure. In the absence of vegetative and outgrowing cells, the spores inactivated by pressure were in stage II (GII) of the germination process. The number of native spores (NS) was calculated by subtracting the total number of germinated spores from the initial concentration of spores $\left(10^{9}\right.$ spores $\left.\mathrm{mL}^{-1}\right)$.

\section{Results}


Germination and inactivation of B. subtilis spores immediately after pressure treatment at $350 \mathrm{MPa}$ and $40^{\circ} \mathrm{C}$

The spore germination and inactivation induced by pressure treatment at $350 \mathrm{MPa}$ and $40{ }^{\circ} \mathrm{C}$, with various holding times, were first studied (Figure 2). Before treatment, we observed that the spores were not inactivated by heat, which means that only native spores were present in the samples. A pressure treatment consisting of a 10 min holding time at $350 \mathrm{MPa}$ (see arrow, Figure 2) directly induced about $1 \log$ of spore destruction. With reference to Table I, this result means that after only $10 \mathrm{~min}$, at least $90 \%$ of the initial population had germinated, had reached stage II of germination (GII), and had become sensitive to pressure. At the same time, the destruction rate achieved with a subsequent heat treatment after a $4 \mathrm{~h}$ holding period at atmospheric pressure was about $4 \log$ (see arrow, Figure 2). Thus, $4 \mathrm{~h}$ after treatment, almost the whole population had already germinated and had reached at least stage I of germination $(\mathrm{GI}+\mathrm{GII})$. Because the initial concentration was about $10^{9}$ spores $\mathrm{mL}^{-1}$ and the heat destruction rate was $4 \log$, only $10^{5}$ spores $\mathrm{mL}^{-1}$ still remained native after the $10 \mathrm{~min}$ holding period at $350 \mathrm{MPa}$.

Increasing the holding time at $350 \mathrm{MPa}$ to $60 \mathrm{~min}$ significantly increased the number of pressure-induced germinated spores $(\mathrm{GI}+\mathrm{GII})$. In fact, the heat-inactivation rate was about 6.5 log for $60 \mathrm{~min}$ at $350 \mathrm{MPa}$. However, only $2 \log$ were directly inactivated (GII) after such a high-pressure treatment. Germination was induced in the main part of the resistant spore population after treatment with $350 \mathrm{MPa}$ for $60 \mathrm{~min}$, however stage II of germination was not achieved. Because the initial concentration was about $10^{9}$ spores $\mathrm{mL}^{-1}$ and $6.5 \log$ of spores had already been heat inactivated, only a small population (about $10^{3}$ spores $\mathrm{mL}^{-1}$ ) still remained native under these conditions.

A further increase in the holding time had little effect on pressure-induced germination (GI + GII) or on pressure-induced inactivation (GII). As shown by the second arrow in Figure 2, the 
direct inactivation of the spores by a pressure treatment of $350 \mathrm{MPa}$ for $4 \mathrm{~h}$ was about $2.5 \log$, whereas the pressure-induced germination of heat-sensitive spores was $6.5 \mathrm{log}$. A small population of native spores was always observed, even when the holding time was prolonged to $24 \mathrm{~h}$ (data not shown). Therefore, pressure appears to rapidly induce spore germination (in the first $30 \mathrm{~min}$ ). It has been reported that it took about 20-30 $\mathrm{min}$ to achieve stage II of germination when spores were induced to germinate by nutrients (Setlow and Johnson, 2007). However, pressure-induced germination was incomplete and the resistant native spores could germinate in the presence of nutrients.

We observed a great difference between pressure-induced inactivation (GII) and pressureinduced germination (GI + GII). Moreover, a long holding time (4 h) at $350 \mathrm{MPa}$ was less efficient in terms of spore destruction (about $2.5 \mathrm{log}$ ) than a holding time of equivalent length at atmospheric pressure after a minimum induction of $10 \mathrm{~min}$ at $350 \mathrm{MPa}$ and a subsequent thermal treatment (more than $4 \mathrm{log}$ ). In the next section, we compare the germination and inactivation that occurred during treatment at $350 \mathrm{MPa}$ with those of previously pressureinduced spores that occurred at atmospheric pressure.

\section{Comparison of spore germination during high-pressure treatment and after pressure treatment at atmospheric pressure}

Spore germination was first induced by a pressure treatment of $350 \mathrm{MPa}$ at $40{ }^{\circ} \mathrm{C}$ for $60 \mathrm{~min}$, and after decompression, the spore suspension was held at atmospheric pressure. After different holding times at atmospheric pressure, the spore suspension was subjected to a heat treatment at $80{ }^{\circ} \mathrm{C}$ for 10 min to identify the development of the pressure-induced germination population $(\mathrm{GI}+\mathrm{GII})$. The pressure-inactivated population (GII) was estimated by subjecting the previously pressure-induced germinated spores to a pressure treatment of $350 \mathrm{MPa} / 40$ ${ }^{\circ} \mathrm{C} / 10$ min. The results are presented in Figure 3, and compared with those for spore germination and inactivation at $350 \mathrm{MPa}$ for different holding times. 
The induction of spore germination after 60 min under pressure, as shown by the GI and GII inactivation curves, did not seem to change, regardless of whether or not the spores were further maintained under pressure. However, germination advancement, as described by the GII inactivation curves, seemed to be more favored when the spores were held at atmospheric pressure than when they were maintained at the same high pressure. After the first pressure treatment for $60 \mathrm{~min}$ at $350 \mathrm{MPa}$, followed by a $60 \mathrm{~min}$ holding period at atmospheric pressure, about $5 \log$ of spores were inactivated by a second pressure treatment, compared with the $2 \log$ of spores that were destroyed after a pressure treatment at $350 \mathrm{MPa}$ with a 120 min holding period. The germination process of the GII spores occurred during the first 60 min after decompression and did not increase significantly thereafter (Figure 3).

Therefore, pressure seems to have two opposite effects on spore germination: the rapid induction but slow completion of the spore germination process. High pressure, which was very efficient in inducing spore germination, seemed to slow the latter stage of the germination process, more particularly the passage from stage I to stage II. In the next step, we focused on the effects of the pressure level on these two events.

\section{Effects of high pressure levels on pressure-induced germination and inactivation}

The effects of high pressure levels on spore germination and inactivation were studied as a function of the pressure level (90-550 MPa). All the experiments were performed with a holding time of $60 \mathrm{~min}$ because this time had been observed to be optimal for the induction of spore germination at $350 \mathrm{MPa}$ (cf. Figure 2). In Figure 4, our results for the inactivation of $B$. subtilis spores after 60 min of pressurization graphed against the pressure levels are compared with the results of Wuytack et al. (1998) for the inactivation of B. subtilis PS832 spores at 40 ${ }^{\circ} \mathrm{C}$ for $30 \mathrm{~min}$ in the same pressure range (Wuytack et al., 1998).

As shown in this figure, Wuytack et al. (1998) found the optimal pressure for spore inactivation near $200 \mathrm{MPa}(2 \mathrm{log}$ ) (Wuytack et al., 1998). Interestingly, in the present study, 
when $B$. subtilis spores were treated for 60 min under pressure, pressure inactivation (GII) was optimal (about $1.82 \mathrm{log}$ ) at roughly the same pressure. Therefore, our results agree with those of Wuytack et al. (1998) in that the inactivation of B. subtilis spores by pressures below $600 \mathrm{MPa}$ at $40{ }^{\circ} \mathrm{C}$ is relatively weak and is not directly proportional to the pressure. Optimal inactivation was observed at moderate pressures (about $250 \mathrm{MPa}$ ), which have little effect on the inactivation of vegetative cells (Gao and Jiang, 2005).

On the contrary, pressure-induced germination depended on high pressures of up to $400 \mathrm{MPa}$. For example, the destruction rate of the total germinated spores (GI + GII) was less than $3 \log$ at $90 \mathrm{MPa}$ compared with $6 \log$ at $350 \mathrm{MPa}$. Further increases in pressure did not result in greater spore induction. Moreover, a pressure of $550 \mathrm{MPa}$ even slightly reduced the spore population induced by pressure. Therefore, the optimal pressure for spore inactivation (about $200 \mathrm{MPa}$ ) is less than the optimal pressure necessary for the induction of spore germination (about $400 \mathrm{MPa}$ ) with a holding time of $60 \mathrm{~min}$. Although pressure inactivation was related to the pressure induction of spore germination, these two phenomena do not have the same optima. This observation supports the hypothesis that high pressure inhibits the achievement of stage II of germination.

\section{Discussion}

The germination phenomena that occur during the high-pressure process are best characterized using the spores' sensitivity to heat and high-pressure treatments and by comparing these phenomena with and without pressure. The effects of high pressure seem to differ greatly depending on the germination stage. This observation could be related to the cellular phenomena involved during germination, which are detailed in the following sections.

\section{How does pressure induce the germination process?}

The mechanisms underlying the high-pressure induction of spore germination seem to depend on the pressure level used. Moderately high pressures (between 50 to $400 \mathrm{MPa}$ ) have been 
reported to induce germination through nutrient receptors, and the subsequent events are processed via the nutrient-triggered germination pathway (Black et al., 2005; Pelczar et al., 2007). Very high pressures (above $400 \mathrm{MPa}$ ) do not activate nutrient receptors but possibly trigger the release of Ca-DPA and the subsequent events of germination (Black et al., 2007; Paidhungat et al., 2002). Our experiments did not show two separate phenomena as a function of the pressure range, and the rate of total spore induction by pressure increased continuously up to $400 \mathrm{MPa}$ (cf. Figure 4). However, the two mechanisms of spore induction could operate together in a certain pressure range. At pressures above $400 \mathrm{MPa}$, the induction phenomenon seemed to be optimal and even decreased slightly with further increases in pressure. A small part of the population ( 1 per $10^{7}$ spores) did not appear to be induced by high pressure.

After the decompression of the first germination-inducing treatment, the number of stage II germinated spores continued to increase, even at atmospheric pressure (cf. Figure 3). Because the spores were suspended in distilled water without nutrients, these results seem to demonstrate that spore germination induced by high pressure is an irreversible process in the absence of nutrients. Thus, high hydrostatic pressure, which is a physical factor like heat, has a very different effect on the induction of spore germination from the effect of heat. It has been reported that, in the absence of nutrients, spore germination can also be induced by sublethal heating (about $80{ }^{\circ} \mathrm{C}$ for $10 \mathrm{~min}$ ), but this induction is reversible because the induced spores return to the dormant state without the addition of nutrients after some time in storage (Keynan et al., 1964).

Moreover, pressure-induced germination is rather rapid and efficient. In fact, about $10^{5}$ spores $\mathrm{mL}^{-1}$ were already induced to germinate after a pressure treatment of $350 \mathrm{MPa}$ at $40{ }^{\circ} \mathrm{C}$ for 30 min, compared with the initial concentration of $10^{9}$ spores $\mathrm{mL}^{-1}$. This short period may be attributable to the fact that the first events of the germination process are passive and do not require enzymatic reactions. Because moderately high pressure induces spore germination by 
activating the spore's nutrient receptors, increasing the pressure to $400 \mathrm{MPa}$ probably supplies more energy to change the conformation of these receptors and consequently enhances spore induction, as shown by the results presented in Figure 4. Wuytack et al. (1998) found no significant differences in the induction of germination by 100 and $400 \mathrm{MPa}$ at $40{ }^{\circ} \mathrm{C}$ (Wuytack et al., 1998). However, their experiments were performed with a shorter holding time (30 min), so the germination rates were low and may not have allowed the observation of differences under these conditions.

We also observed a spore fraction (see the gray area in Figure 5) that was not sensitive to heat immediately after the pressure treatment but germinated later. This spore fraction has some similarities to the activated spores induced by heat and could be called "pressure-activated spores". However, this pressure-activated process was irreversible and the cells proceeded through the next germination stages, even after the pressure was released. These spores are probably at the very first stage of activation and are not sensitive to heat. Otherwise, they are perhaps activated after the high-pressure treatment by a substance excreted from the germinating spores (DPA, $\left.\mathrm{Ca}^{2+} \ldots\right)$.

Finally, the induction of spore germination by pressure was incomplete because a very small spore population (about 1 per $10^{6}$ spores) still remained in their native state in the suspension. However, these spores could germinate in the presence of nutrients after the pressure treatment. Therefore, their nutrient receptors still remained active but were perhaps not sensitive to pressure. This saturation effect could be attributable to the "superdormancy" phenomenon under these conditions but our results did not allow us to confirm this hypothesis. Specific mutants could be useful in evaluating this possibility. Nevertheless, the spore germination induced by moderately high pressure seems slightly different from nutrientinduced germination.

\section{How can pressure affect the progression from stage I to stage II of germination?}


Stage II of germination is related to the hydrolysis of the cortex, the full hydration of the spore core, the restoration of protein mobility and enzyme activity, and the loss of most sporespecific resistance (Cowan et al., 2003; Paidhungat et al., 2002). This germination stage requires the activity of enzymes and normally takes longer than the first stage. Because the progression from stage I (GI) to stage II (GII) is effectively faster at atmospheric pressure than under high pressure (Figure 3), a pressure of $350 \mathrm{MPa}$ ought to slow the transition from GI to GII, probably by lowering the activities of the cortical lytic enzymes and some core enzymes involved in this stage. It has also been reported that germinating spores induced by very high pressures can complete the germination process, but very slowly (Wuytack et al., 1998). Pressure can affect enzyme structures and functionality as well as the kinetics and specificity of the catalyzed reaction. Indeed, the activities of proteolytic and glycolytic enzymes are significantly reduced at pressures higher than $300 \mathrm{MPa}$ (Malone et al., 2003). Similarly, changes in the treatment temperature or $\mathrm{pH}$ can accelerate this progression from stage I to stage II of germination (Stewart et al., 2000). The passage from stage I to stage II of the germinated spores seems to be the limiting step in the germination process under pressure.

\section{Hypothetical mechanisms of spore inactivation under high pressure}

In summary, the effect of the pressure level on the different stages of spore germination and inactivation are shown in Figure 6. Here, we have reported the variations of spore numbers that correspond to each phenomenon as a function of pressure levels.

As shown in Figure 4, pressure-induced germination increased with increasing pressure up to $400 \mathrm{MPa}$. On the contrary, the numbers of spores that proceeded from stage I to stage II of germination decreased with increasing pressure levels. Moreover, as shown previously, stage II germinated spores (GII) lost their specific resistance and the number of GII spores destroyed by pressure increased with increasing pressure, like vegetative cells. The destruction of spores, as influenced by the three processes, is shown in Figure 6. Below 300 
$\mathrm{MPa}$, pressure only weakly inhibited the progression from stage I (GI) to stage II (GII) of germination, but because pressure had little effect on spore induction or the destruction of GII spores, the spore inactivation rate was not high. Pressures above $300 \mathrm{MPa}$ induced the germination of considerable spores, but because the progression from GI to GII was very limited under pressure, the spore inactivation rate was also low. Spore inactivation by high pressure, which is a combination of these three processes, may be optimal at about $250 \mathrm{MPa}$ (Wuytack et al., 1998).

To optimize spore destruction by hydrostatic pressure, different solutions were used, predominantly with a combination of pressure and temperature or with pressure cycling. On the one hand, the higher spore inactivation rate at high temperatures can be explained by the acceleration of enzymatic reactions during the progression from stage I to stage II of germination but also by the fact that stage I germinated spores are directly inactivated by temperatures above $70{ }^{\circ} \mathrm{C}$. On the other hand, the application of pressure cycling is more efficient than a single pressure treatment, when the total exposure is equivalent (Hayakawa et al., 1994). One explanation of this phenomenon is that the repeated rapid decompression causes injury to and disruption and inactivation of the germinated spores (Furukawa et al., 2003). Our results suggest that after the induction of spore germination by the first pressure treatment, the decompression between the pressure cycles favors the progression from stage I to stage II of the germinated spores. The stage II germinated spores are then inactivated by the subsequent pressure cycles, which would explain the greater spore destruction by pressure cycling. Some authors have observed only small differences in spore inactivation between pressure cycling and continuous pressure, probably because the germinated spores were exposed for a very short period to atmospheric pressure and could not proceed further to stage II of germination. The use of pressure cycling with a precise exposure time could significantly enhance spore inactivation by high pressure. For example, a first pressure treatment for 30 
min at $350 \mathrm{MPa}$ and $40{ }^{\circ} \mathrm{C}$, maintenance at atmospheric pressure for $30 \mathrm{~min}$, and a second pressure treatment at $350 \mathrm{MPa}$ and $40{ }^{\circ} \mathrm{C}$ for $10 \mathrm{~min}$ can induce spore destruction of about 5 $\log$.

\section{Conclusion}

The initiation of the germination process is the only way to inactivate spores at pressures below $600 \mathrm{MPa}$ and a moderate temperature $\left(40{ }^{\circ} \mathrm{C}\right)$. Germinated spores were inactivated when they reached stage II of germination. Pressure has two opposite effects on the induction of spore germination and spore inactivation. Pressure is necessary for the induction of spore germination but it slows the progression from stage I germinated spores to stage II germinated spores, and consequently spore inactivation. The completion of spore germination and inactivation by high pressure remains challenging because a small proportion of the spore population (about 1 per $10^{6}$ spores) is not activated by these pressures. These results allow a better comprehension of the effects of pressure on spore germination and inactivation. However, further work is required to better control spore inactivation when applying highpressure processing for food preservation.

\section{References}

Alpas H, Lee J, Bozoglu F, Kaletunc G. 2003. Evaluation of high hydrostatic pressure sensitivity of Staphylococcus aureus and Escherichia coli O157:H7 by differential scanning calorimetry. Int J Food Microbiol 87(3):229-237.

Black EP, Koziol-Dube K, Guan D, Wei J, Setlow B, Cortezzo DE, Hoover DG, Setlow P. 2005. Factors influencing germination of Bacillus subtilis spores via activation of nutrient receptors by high pressure. Appl Environ Microbiol 71(10):5879-5887.

Black EP, Wei J, Atluri S, Cortezzo DE, Koziol-Dube K, Hoover DG, Setlow P. 2007. Analysis of factors influencing the rate of germination of spores of Bacillus subtilis by very high pressure. J Appl Microbiol 102(1):65-76. 
Clery-Barraud C, Gaubert A, Masson P, Vidal D. 2004. Combined effects of high hydrostatic pressure and temperature for inactivation of Bacillus anthracis spores. Appl Environ Microbiol 70(1):635-637.

Cowan AE, Koppel DE, Setlow B, Setlow P. 2003. A soluble protein is immobile in dormant spores of Bacillus subtilis but is mobile in germinated spores: Implications for spore dormancy. Proc Natl Acad Sci U S A 100(7):4209-4214.

Cowan AE, Olivastro EM, Koppel DE, Loshon CA, Setlow B, Setlow P. 2004. Lipids in the inner membrane of dormant spores of Bacillus species are largely immobile. Proc Natl Acad Sci U S A 101(20):7733-7738.

Dose K, Gill M. 1995. DNA stability and survival of Bacillus subtilis spores in extreme dryness. Orig Life Evol Biosph 25(1-3):277-293.

Furukawa S, Shimoda M, Hayakawa I. 2003. Mechanism of the inactivation of bacterial spores by reciprocal pressurization treatment. J Appl Microbiol 94(5):836-841.

Gao YL, Jiang HH. 2005. Optimization of process conditions to inactivate Bacillus subtilis by high hydrostatic pressure and mild heat using response surface methodology. Biochem Eng J 24(1):43-48.

Hayakawa I, Kanno T, Yoshiyama K, Fujio Y. 1994. Oscillatory compared with continuous high pressure sterilization on Bacillus stearothermophilus spores. J Food Sci 59(1):164-167.

Jones CA, Padula NL, Setlow P. 2005. Effect of mechanical abrasion on the viability, disruption and germination of spores of Bacillus subtilis. J Appl Microbiol 99(6):1484-1494.

Keynan A, Evanchik Z, Halvorson HO, Hastings JW. 1964. Activation of bacterial endospores. J Bacteriol 88:313-318. 
Malone AS, Wick C, Shellhammer TH, Courtney PD. 2003. High pressure effects on proteolytic and glycolytic enzymes involved in cheese manufacturing. J Dairy Sci 86(4):1139-1146.

Margosch D, Ganzle MG, Ehrmann MA, Vogel RF. 2004. Pressure inactivation of Bacillus endospores. Appl Environ Microbiol 70(12):7321-7328.

Mathys A, Chapman B, Bull M, Heinz V, Knorr D. 2007. Flow cytometric assessment of Bacillus spore response to high pressure and heat. Inn Food Sci Emer Technol 8(4):519-527.

Moir A. 2003. Bacterial spore germination and protein mobility. Trends Microbiol 11(10):452-454.

Moir A. 2006. How do spores germinate? J Appl Microbiol 101(3):526-530.

Nguyen Thi Minh H, Perrier-Cornet JM, Gervais P. 2008. Effect of the osmotic conditions during sporulation on the subsequent resistance of bacterial spores. Appl Microbiol Biotechnol 80(1):107-114.

Paidhungat M, Setlow B, Daniels WB, Hoover D, Papafragkou E, Setlow P. 2002. Mechanisms of induction of germination of Bacillus subtilis spores by high pressure. Appl Environ Microbiol 68(6):3172-3175.

Paidhungat M, Setlow P. 2002. Spore germination and outgrowth. In: Hoch JA, Losick R, Sonenshein AL, editors. Bacillus subtilis and its relatives: from genes to cells. Washington, DC, USA: ASM. p 537-548.

Pelczar PL, Igarashi T, Setlow B, Setlow P. 2007. Role of GerD in germination of Bacillus subtilis spores. J Bacteriol 189(3):1090-1098.

Perrier-Cornet J-M, Maréchal P-A, Gervais P. 1995. A new design intended to relate high pressure treatment to yeast cell mass transfer. J Biotechnol 41(1):49-58. 
Perrier-Cornet JM, Hayert M, Gervais P. 1999. Yeast cell mortality related to a high-pressure shift: occurrence of cell membrane permeabilization. J Appl Microbiol 87(1):1-7.

Rode LJ, Foster JW. 1960. Mechanical germination of bacterial spores. Proc Natl Acad Sci U S A 46(1):118-128.

Sale AJ, Gould GW, Hamilton WA. 1970. Inactivation of bacterial spores by hydrostatic pressure. J Gen Microbiol 60(3):323-334.

Setlow B, Cowan AE, Setlow P. 2003. Germination of spores of Bacillus subtilis with dodecylamine. J Appl Microbiol 95(3):637-648.

Setlow B, Melly E, Setlow P. 2001. Properties of spores of Bacillus subtilis blocked at an intermediate stage in spore germination. J Bacteriol 183(16):4894-4899.

Setlow P. 2003. Spore germination. Curr Opin Microbiol 6(6):550-556.

Setlow P. 2006. Spores of Bacillus subtilis: their resistance to and killing by radiation, heat and chemicals. J Appl Microbiol 101(3):514-525.

Setlow P, Johnson EA. 2007. Spores and their significance. In: Doyle MP, Beuchat LR, editors. Food Microbiology, Fundamentals and Frontiers. Washington, DC, USA: ASM. p 35-67.

Stewart CM, Dunne CP, Sikes A, Hoover DG. 2000. Sensitivity of spores of Bacillus subtilis and Clostridium sporogenes PA 3679 to combinations of high hydrostatic pressure and other processing parameters. Inn Food Sci Emer Technol 1(1):49-56.

Tewari G, Jayas DS, Holley RA. 1999. High pressure processing of foods: an overview. Sciences des Aliments 19(6):619-661.

Timson WJ, Short AJ. 1965. Resistance of microorganisms to hydrostatic pressure. Biotechnol Bioeng 7(1):139-159.

Vreeland RH, Rosenzweig WD, Powers DW. 2000. Isolation of a 250 million-year-old halotolerant bacterium from a primary salt crystal. Nature 407(6806):897-900 
Wuytack EY, Boven S, Michiels CW. 1998. Comparative study of pressure-induced germination of Bacillus subtilis spores at low and high pressures. Appl Environ Microbiol 64(9):3220-3224. 


\section{Figure captions}

Figure 1. Different stages of spore germination (Setlow, 2003).

Figure 2. Spore germination $(\diamond)$ and inactivation $(\boldsymbol{\Delta})$ immediately after a pressure treatment at $350 \mathrm{MPa}$ at $40{ }^{\circ} \mathrm{C}$ for different holding times. (GI) stage I germinated spores; (GII) stage II germinated spores; $(\mathrm{P})$ pressure treatment; and $(\mathrm{H})$ heat treatment.

Figure 3. Comparison of the germination and inactivation of B. subtilis spores immediately after pressure treatment at $350 \mathrm{MPa} / 40{ }^{\circ} \mathrm{C}$ (-) and those induced by high-pressure treatment at $350 \mathrm{MPa} / 40{ }^{\circ} \mathrm{C} / 60 \mathrm{~min}$, followed by atmospheric pressure $(---)$. ( $\left.\mathbf{\Delta}\right)$ inactivation by pressure; $(\downarrow)$ germination induced by pressure; $(\mathrm{P})$ pressure treatment; and $(\mathrm{H})$ heat treatment.

Figure 4. Effects of the pressure level on the inactivation (*) and germination ( $\bullet$ ) of B. subtilis spores induced by high-pressure treatments at $40{ }^{\circ} \mathrm{C}$ for $60 \mathrm{~min}$ observed in this study and the inactivation results for B. subtilis spores after high-pressure treatments at $40{ }^{\circ} \mathrm{C}$ for $30 \mathrm{~min}$ ( $\boldsymbol{\Delta}$ ) observed by Wuytack et al. (1998). (P) pressure treatment; and (H) heat treatment.

Figure 5. Pressure inactivation $(\boldsymbol{\Delta})$ and pressure-induced germination $(\bullet)$ as a function of holding time at atmospheric pressure after the pressure treatment $\left(350 \mathrm{MPa} / 40{ }^{\circ} \mathrm{C} / 60 \mathrm{~min}\right)$ for the induction of germination.

Figure 6. Schematic diagram of the effects of the pressure level on the different stages of spore germination and inactivation. 
Table I. Tests used to quantify each spore population after the pressure-induced germination process. Native spores (NS), stage I germinated spores (GI), stage II germinated spores (GII), pressure treatment $(\mathbf{P})$, and heat treatment $(\mathbf{H})$.

\begin{tabular}{ccccc}
\hline Successive treatment & Test schema & $\begin{array}{c}\text { Resistant } \\
\text { fraction }\end{array}$ & $\begin{array}{c}\text { Inactivated } \\
\text { fraction }\end{array}$ & Phenomenon \\
\hline Pressure treatment $\left(350 \mathrm{MPa} / 40^{\circ} \mathrm{C}\right)$ & $\mathrm{NS}+\mathrm{GI}$ & $\mathrm{GII}$ & $\begin{array}{c}\text { Pressure } \\
\text { inactivation }\end{array}$ \\
$\begin{array}{c}\text { Pressure treatment } \\
+4 \mathrm{~h}(\text { Atmospheric pressure }) \\
+ \text { Heat treatment }\left(80{ }^{\circ} \mathrm{C} / 10 \mathrm{~min}\right)\end{array}$ & $\mathrm{P}$ & $\mathrm{NS}$ & $\mathrm{GI}+\mathrm{GII}$ & $\begin{array}{c}\text { Pressure- } \\
\text { induced } \\
\text { germination }\end{array}$ \\
\hline
\end{tabular}


Figure 1. Different stages of spore germination (Setlow, 2003)

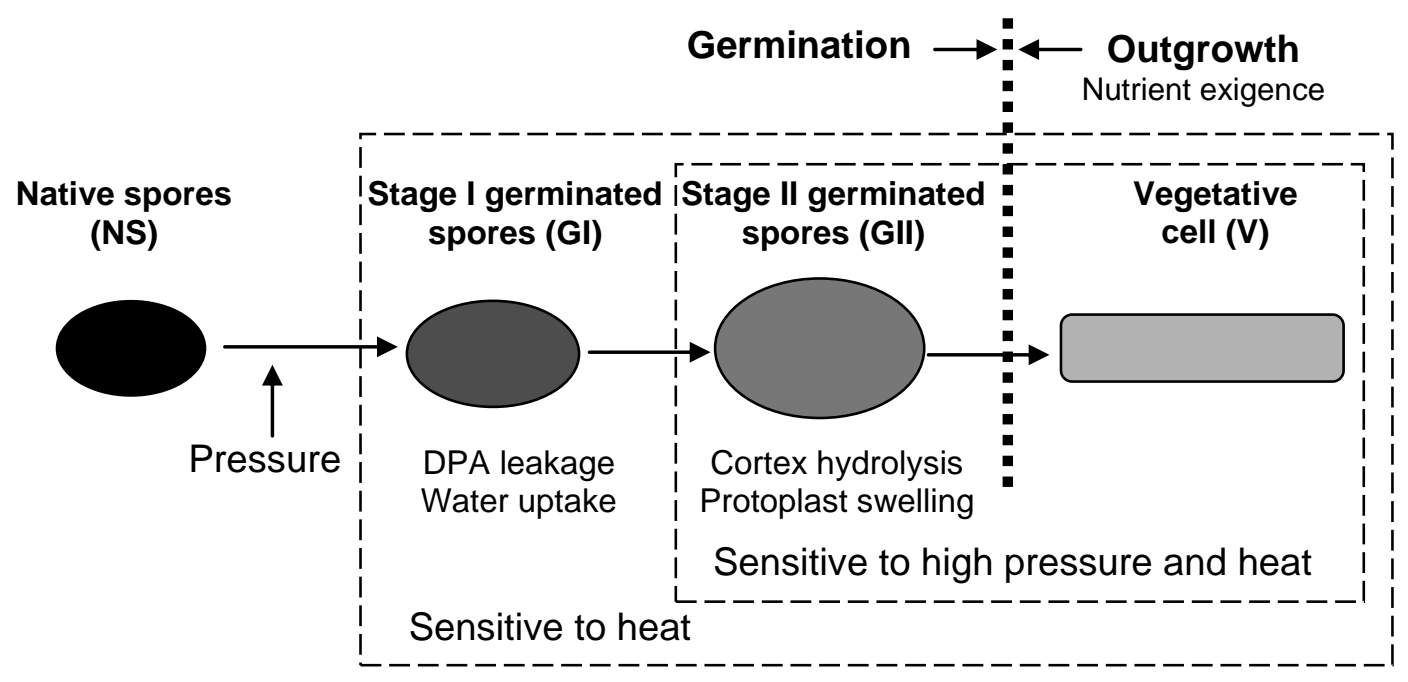


Figure 2. Spore germination $(\diamond)$ and inactivation $(\Delta)$ immediately after a pressure treatment at $350 \mathrm{MPa}$ at $40{ }^{\circ} \mathrm{C}$ for different holding times. (GI) stage I germinated spores; (GII) stage II germinated spores; (P) pressure treatment; and $(\mathrm{H})$ heat treatment.

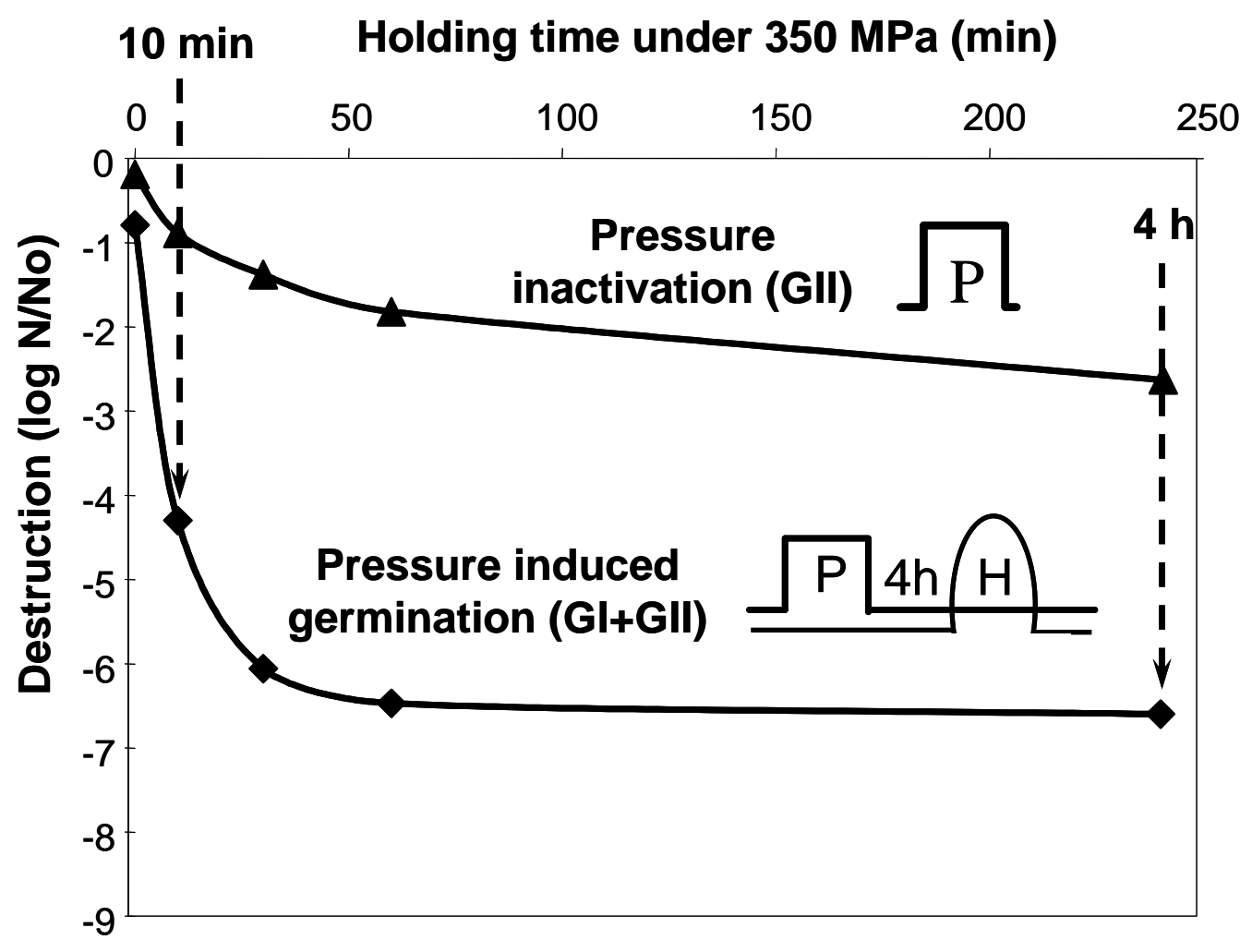


Figure 3. Comparison of the germination and inactivation of $\mathrm{B}$. subtilis spores immediately after pressure treatment at $350 \mathrm{MPa} / 40{ }^{\circ} \mathrm{C}(-)$ and those induced by high-pressure treatment at $350 \mathrm{MPa} / 40{ }^{\circ} \mathrm{C} / 60$ min, followed by atmospheric pressure $(---)$. $(\Delta)$ inactivation by pressure; $(\diamond)$ germination induced by pressure; $(\mathrm{P})$ pressure treatment; and $(\mathrm{H})$ heat treatment.

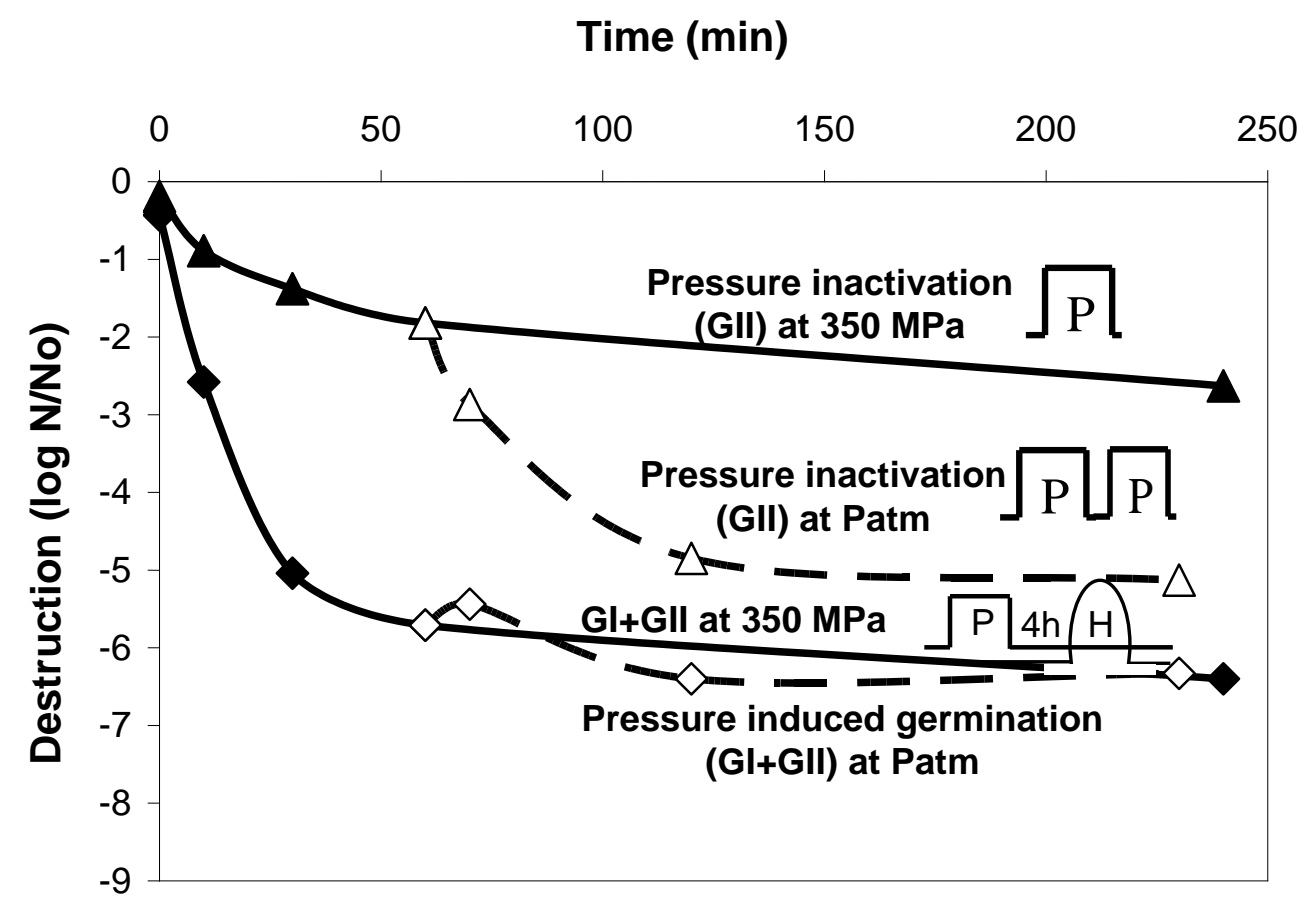


Figure 4. Effects of the pressure level on the inactivation (*) and germination ( $\diamond)$ of B. subtilis spores induced by high-pressure treatments at $40{ }^{\circ} \mathrm{C}$ for $60 \mathrm{~min}$ observed in this study and the inactivation results for $B$. subtilis spores after high-pressure treatments at $40{ }^{\circ} \mathrm{C}$ for $30 \mathrm{~min}(\Delta)$ observed by Wuytack et al. (1998). (P) pressure treatment; and (H) heat treatment.

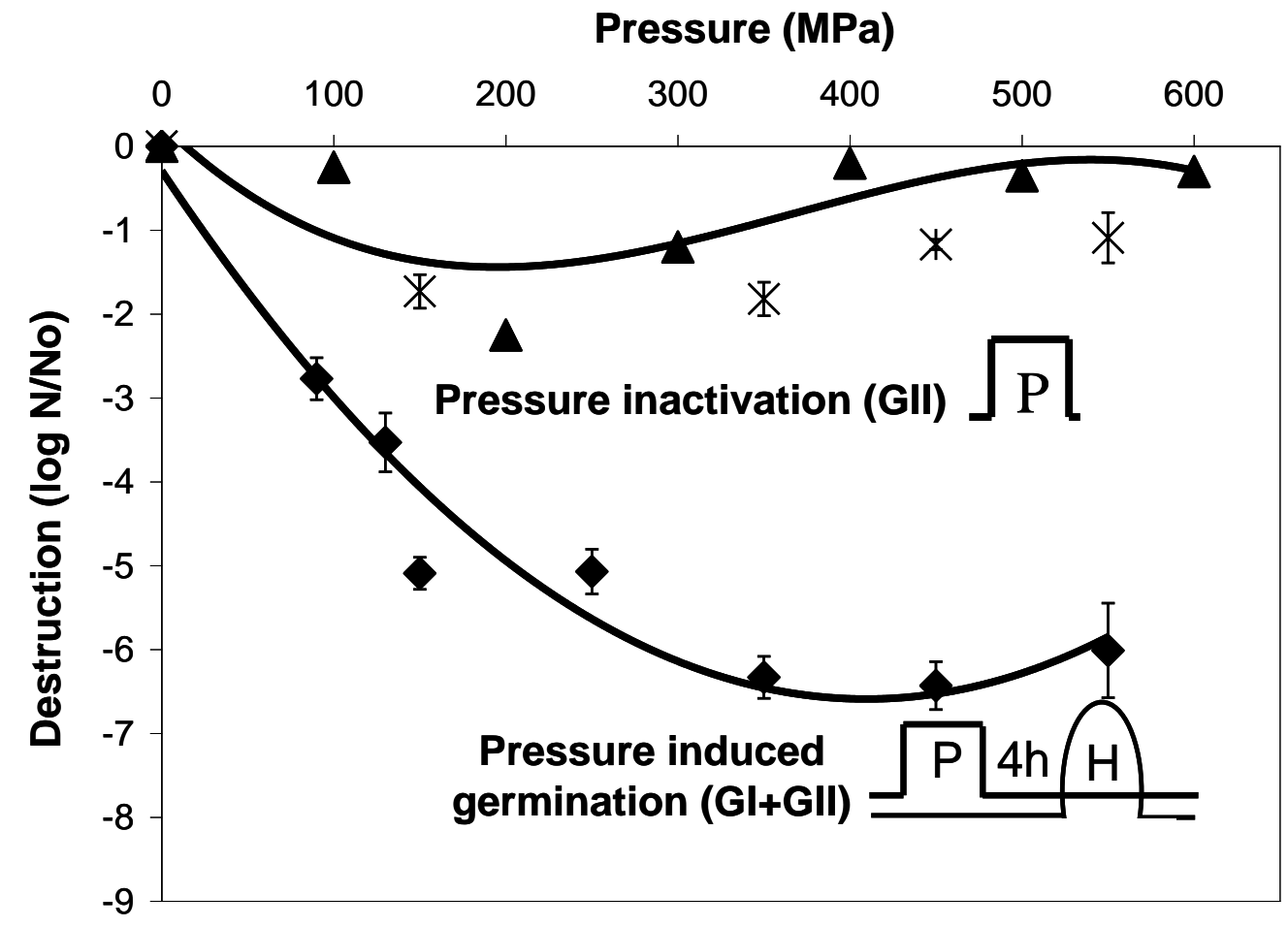


Figure 5. Pressure inactivation $(\Delta)$ and pressure-induced germination $(\diamond)$ as a function of holding time at atmospheric pressure after the pressure treatment $\left(350 \mathrm{MPa} / 40{ }^{\circ} \mathrm{C} / 60 \mathrm{~min}\right)$ for the induction of germination.

Holding time at Patm (min)

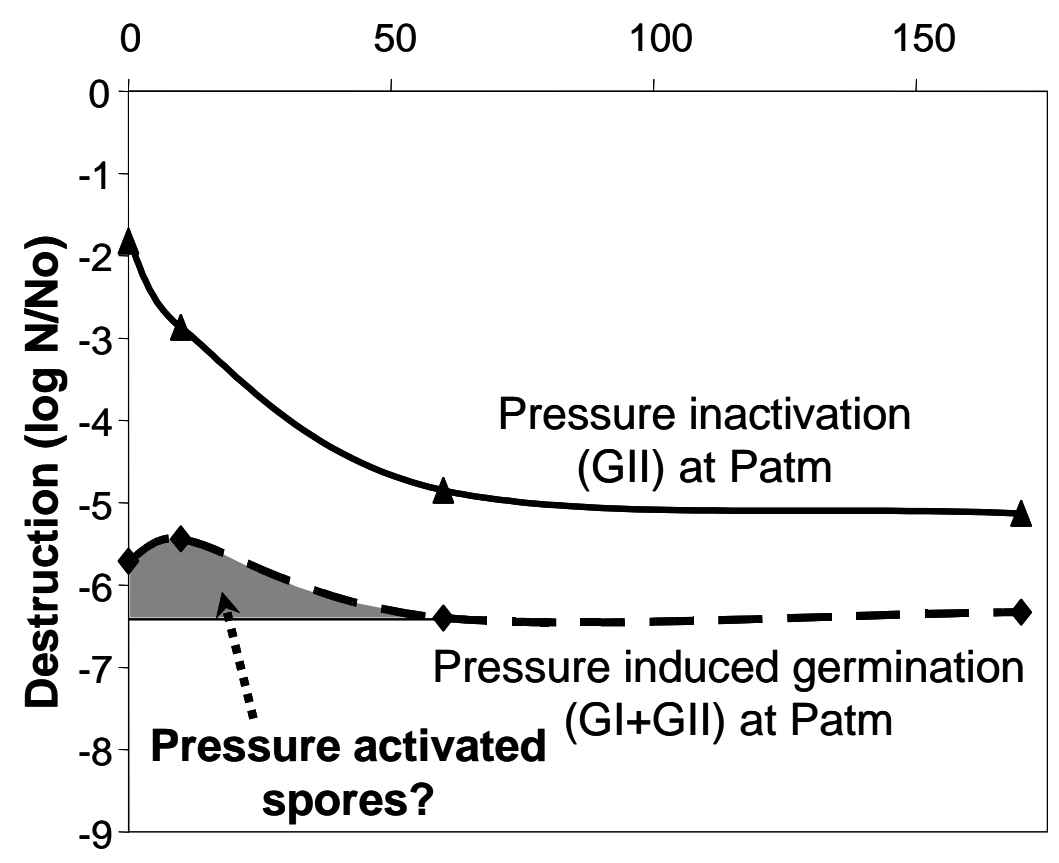


Figure 6. Schematic diagram of the effects of the pressure level on the different stages of spore germination and inactivation.

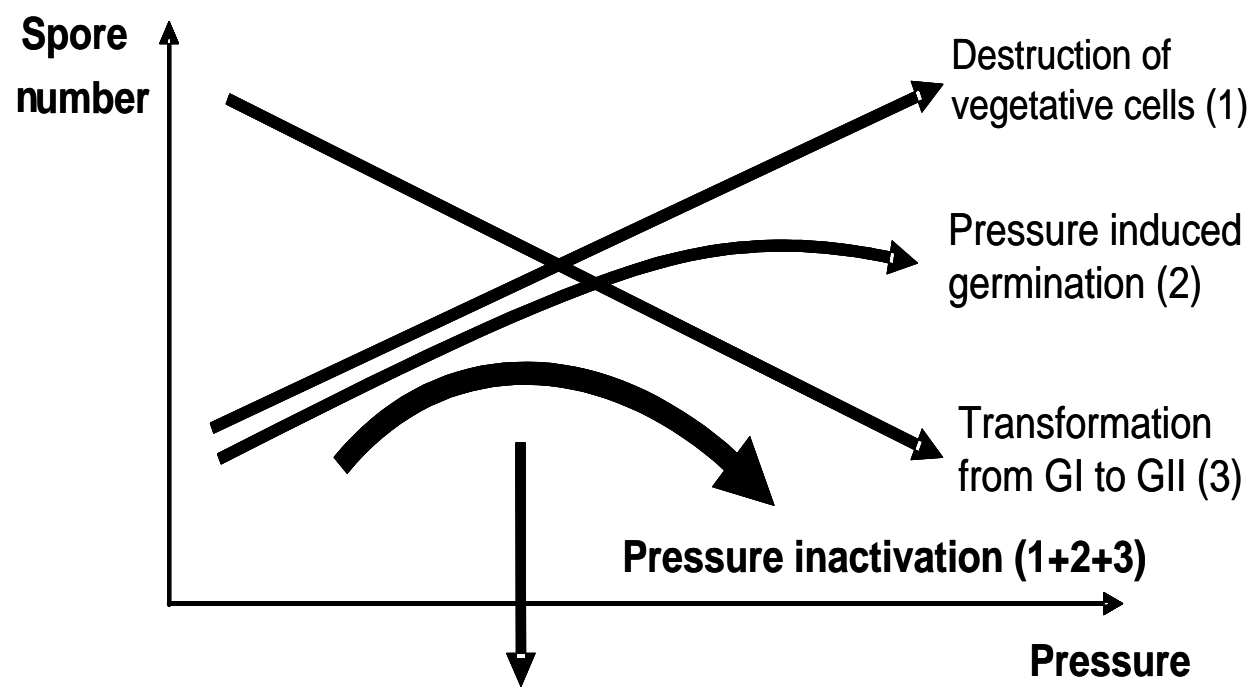

Optimal pressure for spore destruction 